\title{
Pop artist displays primitive instincts
}

\section{A retrospective of Todd Schorr's huge oil-painted comic-book visions features his garish image of a hunter-gatherer. Is it a deliberate allegory of consumer culture, asks Martin Kemp?}

Sci-fi comics have a look of their own. Their style has changed over the years in response to new print technologies, but they display recurrent visual characteristics that are easy to list. Alien creatures have monstrous heads, leering eyes, savage claws, snaking tentacles and scaly skins. Mechanized organisms do battle with anthropomorphized machines. The paraphernalia and costumes are oddly Gothick; galactic spaces plunge and swirl; and phosphorescent lights compete with devouring darkness. All of this is rendered in lurid colours with exaggerated outlines that shout of violent action and rude excitement.

There seems to be little here to align with 'high art'. However, in the mid-1950s, American and British artists in the pop art movement, such as Andy Warhol and Richard Hamilton, imported imagery and techniques from the commercial world and from 'lowbrow' sources including comics and cartoons. Lowbrow art became a movement in itself, centred on Los Angeles in California from the 1970s onwards, adopting the cartoon style as its major characteristic.

No one has gone to more elaborate lengths than the painter Todd Schorr to transfer lowbrow modes of representation to the 'high' technique of oil painting on canvas - often on a very large scale. Schorr, who is based in Los Angeles, has a background that is perfect for this end.

Starting out as a drummer in rock bands, Schorr was captivated by the culture of psychedelia before training as an illustrator at the Philadelphia College of Art in Pennsylvania. His career flourished: he produced album covers for AC/DC, film posters for Francis Ford Coppola and covers for Time magazine. But, like Warhol before him, he progressively detached himself from commercial work to pursue a career as a fine artist.

Schorr characterizes his paintings as an American variety of surrealism. His heroes are Salvador Dalí, that most technically polished of surrealists, and the Renaissance maestro of bizarre organic inventions, Jerome Bosch. The competition is therefore tough, both technically and inventively.

How far does Schorr's loving transposition of lowbrow modes into art for galleries transcend his 'vulgar' sources? The professional illustrators of comics, pulp fiction and animated cartoons did their work with precise skills and superb draftsmanship. Looking at Schorr's retrospective exhibition in the San Jose Museum of Art in California, there are times when it seems

A laughing Mohican is dressed in the uniform of an Atlanta Braves baseball player. The palaeolithic Willendorf Venus dances with a stubbly and lecherous Mickey Mouse on a disco platform cut from the bloody leg of an ungulate. Another mouse in the ape's grip, presumably Minnie, plays the part performed so tellingly by Fay Wray in the 1933 film King Kong. Fronds of primitive equiseta spiral upwards into a vortex that is reminiscent of Paul Signac's pointillist portrait of Félix Fénéon from 1890 (at the Museum of Modern Art in New York).

At one level, Schorr is revelling in the look of lowbrow culture. Yet once this is portrayed on the heroic scale of a historical painting on the walls of an art gallery, we are invited to adopt an ironic manner of viewing. Like all pop artists, he is having his cake and eating it too, only to spit it out at the end. We may intuit that the hunter-gatherer in Schorr's painting suggests that the apeman's primitive instinct for acquiring material trivia still drives our consumer culture today.

However, to formulate too fixed an interpretation is wrong. Unlike a

that he is achieving little more than a collage of pop motifs in a stock surrealistic mode.

On other occasions, however, the narrative and symbolism move to a different level. This is particularly true of his recent series of ape paintings, which range across chronological territories from the remote past to the sci-fi future. Hunter Gatherer (owned by Leonardo di Caprio) garishly exemplifies how Schorr tells his stories and enriches them with intricate symbolism. We need to decode the whole and the parts in much the same way that a historical iconographer would tackle a Botticelli painting on a classical theme.

A humanoid ape emerges from a bubbling swamp, apparently amazed by the sight of a toy space robot. On his back, like Santa Claus, he carries a roughly stitched sack of cartoon character toys, including Batman. frame from a comic-book cartoon, the narrative is not spelled out by successive images and strings of words. The painting acts as an inviting field for interpretation.

Will Schorr be regarded as a major visual allegorist of our age, as was Botticelli in the Renaissance? For my part, I find it difficult to get past the unpleasantly garish rendering and unsubtle storytelling. But that is the point. The lowbrow artists are attuned to a major facet of our visual culture. And they are very Californian.

Martin Kemp is emeritus professor in history of art at the University of Oxford, Oxford, UK.

Todd Schorr: American Surreal San Jose Museum of Art, California Until 16 September 